\title{
A Revision to Industrial Production and Capacity Utilization, 1991-95
}

Richard D. Raddock, of the Board's Division of Research and Statistics, prepared this article.

The Federal Reserve's index of industrial production (IP) and its related measures of capacity and utilization for January 1991 onward have been revised (tables 1.A. and 1.B). The updated indexes for total IP and for manufacturing show slower growth for 1993 and faster growth for 1994 than was previously estimated. For 1995, the level of the revised production indexes for both major aggregates are, on balance, about the same as previously reported. Capacity growth, however, is now estimated to have been a fraction of a percentage point higher over the period of the revision. As a result, the rates of capacity utilization last summer for total IP and for manufacturing are slightly lower than previously reported. The updated measures continue to paint the same

1.A. Revised data for industrial production, capacity, and utilization for total industry, 1988-95

Seasonally adjusted data, except as noted

\begin{tabular}{|c|c|c|c|c|c|c|c|c|c|c|c|c|c|c|c|c|c|}
\hline \multirow{2}{*}{ Year } & \multirow{2}{*}{ Jan. } & \multirow{2}{*}{ Feb. } & \multirow{2}{*}{ Mar. } & \multirow{2}{*}{ Apr. } & \multirow{2}{*}{ May } & \multirow{2}{*}{ June } & \multirow{2}{*}{ July } & \multirow{2}{*}{ Aug. } & \multirow{2}{*}{ Sept. } & \multirow{2}{*}{ Oct. } & \multirow{2}{*}{ Nov. } & \multirow{2}{*}{ Dec. } & \multicolumn{4}{|c|}{ Quarter } & \multirow{2}{*}{$\begin{array}{l}\text { Annual } \\
\text { avg. }{ }^{2}\end{array}$} \\
\hline & & & & & & & & & & & & & 1 & 2 & 3 & 4 & \\
\hline & \multicolumn{17}{|c|}{ Industrial production (percentage change) } \\
\hline 1988 & .3 & .2 & .0 & .8 & -.3 & .0 & .6 & 6 & -.5 & .3 & .6 & 6 & 3.8 & 3.0 & 2.9 & 3.0 & 4.4 \\
\hline 1989 & .3 & -.5 & 9 & .0 & -.3 & -.3 & -1.0 & .5 & -.4 & -.4 & .4 & .7 & 3.9 & .3 & -4.4 & -.2 & 1.5 \\
\hline 1990 & -.5 & .5 & .3 & -.7 & .7 & .2 & -.2 & .3 & .0 & -.5 & -1.3 & -.4 & 2.1 & 1.1 & 1.6 & -5.2 & .0 \\
\hline 1991 & -.5 & -1.0 & -.8 & .3 & .8 & 1.1 & .2 & .3 & .8 & .1 & -.1 & -.5 & -8.4 & 1.1 & 6.7 & 2.0 & -1.8 \\
\hline 1992 & -.1 & .6 & .9 & .7 & .5 & -.3 & .8 & -.2 & .2 & .7 & .6 & .2 & .8 & 7.0 & 3.1 & 4.9 & 3.4 \\
\hline 1993 & .3 & .4 & .0 & .2 & -.5 & .2 & .6 & .0 & .7 & .1 & .7 & .9 & 3.7 & .5 & 3.2 & 5.5 & 3.5 \\
\hline 1994 & .4 & .8 & .8 & .3 & .5 & .5 & .2 & .5 & .1 & .7 & .5 & .8 & 8.4 & 7.0 & 4.6 & 6.4 & 5.9 \\
\hline \multirow[t]{2}{*}{1995} & .3 & -.1 & .1 & -.4 & .0 & .1 & .1 & 1.1 & .1 & -.4 & & $\ldots$ & 3.9 & -1.4 & 3.6 & $\ldots$ & $\ldots$ \\
\hline & \multicolumn{17}{|c|}{ Industrial production } \\
\hline 1988 & 103.2 & 103.4 & 103.4 & 104.3 & 104.0 & 104.0 & 104.6 & 105.2 & 104.7 & 105.0 & 105.6 & 106.3 & 103.3 & 104.1 & 104.8 & 105.6 & 104.4 \\
\hline 1989 & 106.6 & 106.2 & 107.1 & 107.1 & 106.7 & 106.4 & 105.3 & 105.8 & 105.4 & 105.0 & 105.4 & 106.1 & 106.6 & 106.7 & 105.5 & 105.5 & 106.0 \\
\hline 1990 & 105.5 & 106.1 & 106.4 & 105.7 & 106.5 & 106.7 & 106.5 & 106.8 & 106.8 & 106.3 & 105.0 & 104.5 & 106.0 & 106.3 & 106.7 & 105.3 & 106.0 \\
\hline 1991 & 104.0 & 102.9 & 102.1 & 102.4 & 103.2 & 104.3 & 104.5 & 104.8 & 105.7 & 105.8 & 105.6 & 105.1 & 103.0 & 103.3 & 105.0 & 105.5 & 104.2 \\
\hline 1992 & 105.0 & 105.6 & 106.5 & 107.3 & 107.8 & 107.5 & 108.4 & 108.2 & 108.4 & 109.2 & 109.8 & 110.0 & 105.7 & 107.5 & 108.3 & 109.7 & 107.7 \\
\hline 1993 & 110.4 & 110.8 & 110.8 & 111.1 & 110.6 & 110.8 & 111.4 & 111.4 & 112.2 & 112.3 & 113.1 & 114.1 & 110.7 & 110.8 & 111.7 & 113.2 & 111.5 \\
\hline 1994 & 114.6 & 115.5 & 116.4 & 116.8 & 117.5 & 118.1 & 118.4 & 118.9 & 119.1 & 119.9 & 120.5 & 121.5 & 115.5 & 117.5 & 118.8 & 120.6 & 118.1 \\
\hline \multirow[t]{2}{*}{1995} & 121.8 & 121.7 & 121.9 & 121.4 & 121.3 & 121.4 & 121.5 & 122.9 & 123.0 & 122.5 & $\ldots$ & & 121.8 & 121.4 & 122.5 & $\ldots$ & $\ldots$ \\
\hline & \multicolumn{17}{|c|}{ Capacity } \\
\hline 1988 & 123.9 & 124.1 & 124.2 & 124.4 & 124.5 & 124.7 & 124.8 & 125.0 & 125.1 & 125.3 & 125.4 & 125.5 & 124.1 & 124.5 & 125.0 & 125.4 & 124.7 \\
\hline 1989 & 125.7 & 125.9 & 126.1 & 126.3 & 126.5 & 126.7 & 126.9 & 127.1 & 127.3 & 127.5 & 127.7 & 127.9 & 125.9 & 126.5 & 127.1 & 127.7 & 126.8 \\
\hline 1990 & 128.1 & 128.3 & 128.5 & 128.7 & 128.9 & 129.1 & 129.3 & 129.5 & 129.7 & 129.9 & 130.1 & 130.3 & 128.3 & 128.9 & 129.5 & 130.1 & 129.2 \\
\hline 1991 & 130.5 & 130.7 & 130.9 & 131.1 & 131.3 & 131.5 & 131.7 & 131.9 & 132.1 & 132.3 & 132.5 & 132.7 & 130.7 & 131.3 & 131.9 & 132.5 & 131.6 \\
\hline 1992 & 132.9 & 133.2 & 133.4 & 133.6 & 133.9 & 134.1 & 134.3 & 134.6 & 134.8 & 135.1 & 135.3 & 135.5 & 133.2 & 133.9 & 134.6 & 135.3 & 134.2 \\
\hline 1993 & 135.8 & 136.0 & 136.3 & 136.5 & 136.7 & 137.0 & 137.2 & 137.5 & 137.7 & 137.9 & 138.2 & 138.4 & 136.0 & 136.7 & 137.5 & 138.2 & 137.1 \\
\hline 1994 & 138.7 & 139.1 & 139.5 & 139.8 & 140.2 & 140.5 & 140.9 & 141.3 & 141.7 & 142.0 & 142.4 & 142.8 & 139.1 & 140.2 & 141.3 & 142.4 & 140.8 \\
\hline \multirow[t]{2}{*}{1995 . } & 143.2 & 143.6 & 144.1 & 144.5 & 145.0 & 145.5 & 145.9 & 146.4 & 146.9 & 147.3 & $\ldots$ & $\ldots$ & 143.7 & 145.0 & 146.4 & $\ldots$ & $\ldots$ \\
\hline & & & & & & & & & tilizatio & & & & & & & & \\
\hline 1988 & 83.2 & 83.3 & 83.2 & 83.8 & 83.5 & 83.4 & 83.8 & 84.2 & 83.7 & 83.8 & 84.2 & 84.6 & 83.3 & 83.6 & 83.9 & 84.2 & 83.7 \\
\hline 1989 & 84.8 & 84.3 & 84.9 & 84.8 & 84.3 & 83.9 & 83.0 & 83.3 & 82.8 & 82.3 & 82.5 & 82.9 & 84.7 & 84.3 & 83.0 & 82.6 & 83.7 \\
\hline 1990 & 82.4 & 82.7 & 82.8 & 82.1 & 82.6 & 82.6 & 82.4 & 82.5 & 82.4 & 81.8 & 80.7 & 80.2 & 82.6 & 82.5 & 82.4 & 80.9 & 82.1 \\
\hline 1991 & 79.7 & 78.7 & 78.0 & 78.1 & 78.6 & 79.3 & 79.4 & 79.4 & 80.0 & 79.9 & 79.7 & 79.2 & 78.8 & 78.7 & 79.6 & 79.6 & 79.2 \\
\hline 1992 & 78.9 & 79.3 & 79.9 & 80.3 & 80.5 & 80.2 & 80.7 & 80.4 & 80.4 & 80.8 & 81.2 & 81.2 & 79.4 & 80.3 & 80.5 & 81.0 & 80.3 \\
\hline 1993 & 81.3 & 81.5 & 81.4 & 81.4 & 80.9 & 80.9 & 81.2 & 81.1 & 81.5 & 81.4 & 81.8 & 82.4 & 81.4 & 81.0 & 81.2 & 81.9 & 81.4 \\
\hline 1994 & 82.6 & 83.0 & 83.5 & 83.6 & 83.8 & 84.0 & 84.0 & 84.2 & 84.0 & 84.4 & 84.6 & 85.1 & 83.0 & 83.8 & 84.1 & 84.7 & 83.9 \\
\hline 1995 & 85.1 & 84.7 & 84.6 & 84.0 & 83.7 & 83.5 & 83.3 & 83.9 & 83.7 & 83.2 & $\ldots$ & $\ldots$ & 84.8 & 83.7 & 83.6 & . & \\
\hline
\end{tabular}

Note. Estimates from August 1995 through October 1995 are subject to further revision in the upcoming monthly releases.
1. Annual averages of industrial production are calculated from not seasonally adjusted indexes. 
broad picture of recovery in industrial activity from the 1990 recession through 1994, followed by a slowdown in early 1995 (chart 1).

\section{PRODUCTION}

The new estimates of production incorporate additional or updated figures from several sources. Revised annual figures include the following: data from the 1992 Census of Manufactures, preliminary results of the 1993 Annual Survey of Manufactures, physical data on mining for 1994, and data for 1994 reported in selected Current Industrial Reports published by the Bureau of the Census. The revision also incorporated updated monthly source data. The downward revision to IP growth for 1993 largely resulted from incorporating the data from the Annual Survey of Manufactures (table 2). However, the inclusion of the new annual and monthly data produced higher estimates of growth for 1994. Other aspects of the revi- sion included revised seasonal factors, which were calculated using the X-11 ARIMA program from Statistics Canada, through mid-1995, and the updating of the productivity relationships that are applied to input-based estimates. The weights used since 1992 to aggregate the series continue to be proportions based on value added by industries in 1992. The production and capacity indexes continue to be expressed as percentages of output in 1987.

Despite noticeable changes in some component series, the indexes for the output of business equipment and durable materials continue to show the strong upward trends that emerged in 1991 (chart 2). The sustained, exceptionally rapid growth in output of high technology goods has been a major factor in these trends. The indexes for consumer durables and construction supplies still show a substantial falloff from the beginning of 1995 , although the production of consumer durables is now estimated to have been at a higher level before beginning its drop. The

1.B. Revised data for industrial production, capacity, and utilization for manufacturing industries, 1988-95 Seasonally adjusted data, except as noted

\begin{tabular}{|c|c|c|c|c|c|c|c|c|c|c|c|c|c|c|c|c|c|}
\hline \multirow{2}{*}{ Yea } & \multirow{2}{*}{ Jan. } & \multirow{2}{*}{ Feb. } & \multirow{2}{*}{ Mar. } & \multirow{2}{*}{ Apr. } & \multirow{2}{*}{ May } & \multirow{2}{*}{ June } & \multirow{2}{*}{ July } & \multirow{2}{*}{ Aug. } & \multirow{2}{*}{ Sept. } & \multirow{2}{*}{ Oct. } & \multirow{2}{*}{ Nov. } & \multirow{2}{*}{ Dec. } & \multicolumn{4}{|c|}{ Quarter } & \multirow{2}{*}{$\begin{array}{l}\text { Annual } \\
\text { avg. }{ }^{2}\end{array}$} \\
\hline & & & & & & & & & & & & & 1 & 2 & 3 & 4 & \\
\hline & \multicolumn{17}{|c|}{ Industrial production (percentage change) } \\
\hline 1988 & .2 & .1 & .2 & .7 & -.1 & .0 & .5 & .4 & .0 & .1 & .9 & .6 & 3.6 & 3.3 & 3.0 & 4.4 & 4.7 \\
\hline 1989 & .8 & -.9 & .6 & .2 & -.5 & -.2 & -1.2 & .4 & -.4 & -.5 & .3 & .2 & 4.3 & -.3 & -5.3 & -1.3 & 1.6 \\
\hline 1990 & -.1 & .9 & .4 & -.9 & .5 & .0 & -.3 & .5 & -.1 & -.6 & -1.2 & -.5 & 3.7 & .2 & 1.0 & -5.5 & -.3 \\
\hline 1991 & -.9 & -.9 & -.9 & .3 & .7 & 1.3 & .3 & .3 & 1.0 & .1 & -.2 & -.4 & -9.8 & 1.0 & 8.1 & 2.5 & -2.1 \\
\hline 1992 & .1 & .8 & .9 & 6 & .6 & .0 & .8 & -.1 & .1 & 6 & .6 & .0 & 2.3 & 7.6 & 3.8 & 4.3 & 4.2 \\
\hline 1993 & .8 & .3 & .0 & .4 & -.4 & .0 & .6 & -.1 & .9 & .0 & .8 & 1.1 & 4.6 & 1.2 & 3.0 & 6.0 & 3.9 \\
\hline 1994 & .2 & .9 & 1.0 & .6 & .6 & .3 & .4 & .6 & .2 & .9 & .6 & .9 & 8.9 & 8.5 & 5.1 & 7.9 & 6.6 \\
\hline \multirow[t]{2}{*}{1995} & .3 & -.2 & .1 & -.4 & -.3 & .1 & .0 & .9 & .5 & -.3 & $\ldots$ & $\ldots$ & 3.9 & -2.2 & 3.1 & $\ldots$ & $\ldots$ \\
\hline & \multicolumn{17}{|c|}{ Industrial production } \\
\hline 1988 & 103.2 & 103.4 & 103.6 & 104.3 & 104.2 & 104.2 & 104.7 & 105.1 & 105.2 & 105.3 & 106.2 & 106.8 & 103.4 & 104.2 & 105.0 & 106.1 & 104.7 \\
\hline 1989 & 107.7 & 106.7 & 107.3 & 107.6 & 107.1 & 106.8 & 105.5 & 106.0 & 105.6 & 105.1 & 105.4 & 105.6 & 107.2 & 107.2 & 105.7 & 105.4 & 106.4 \\
\hline 1990 & 105.5 & 106.5 & 107.0 & 106.0 & 106.6 & 106.6 & 106.3 & 106.9 & 106.8 & 106.2 & 104.9 & 104.4 & 106.3 & 106.4 & 106.6 & 105.1 & 106.1 \\
\hline 1991 & 103.4 & 102.5 & 101.5 & 101.8 & 102.5 & 103.8 & 104.2 & 104.5 & 105.6 & 105.7 & 105.5 & 105.1 & 102.5 & 102.7 & 104.8 & 105.4 & 103.8 \\
\hline 1992 & 105.1 & 105.9 & 106.9 & 107.6 & 108.2 & 108.1 & 109.0 & 108.9 & 109.0 & 109.7 & 110.4 & 110.3 & 106.0 & 108.0 & 109.0 & 110.1 & 108.2 \\
\hline 1993 & 111.2 & 111.5 & 111.5 & 112.0 & 111.6 & 111.6 & 112.3 & 112.2 & 113.2 & 113.2 & 114.1 & 115.3 & 111.4 & 111.7 & 112.5 & 114.2 & 112.3 \\
\hline 1994 & 115.5 & 116.6 & 117.8 & 118.5 & 119.1 & 119.5 & 120.0 & 120.7 & 120.9 & 122.0 & 122.7 & 123.8 & 116.6 & 119.0 & 120.5 & 122.8 & 119.7 \\
\hline \multirow[t]{2}{*}{1995} & 124.1 & 123.9 & 124.0 & 123.5 & 123.2 & 123.3 & 123.3 & 124.5 & 125.0 & 124.7 & $\cdots$ & $\cdots$ & 124.0 & 123.3 & 124.3 & $\ldots$ & $\cdots$ \\
\hline & \multicolumn{17}{|c|}{ Capacity } \\
\hline 1988 & 124.1 & 124.3 & 124.5 & 124.7 & 124.9 & 125.1 & 125.3 & 125.5 & 125.7 & 125.9 & 126.0 & 126.2 & 124.3 & 124.9 & 125.5 & 126.0 & 125.2 \\
\hline 1989 & 126.5 & 126.7 & 127.0 & 127.2 & 127.4 & 127.7 & 127.9 & 128.2 & 128.4 & 128.7 & 128.9 & 129.2 & 126.7 & 127.4 & 128.2 & 128.9 & 127.8 \\
\hline 1990 & 129.4 & 129.6 & 129.8 & 130.1 & 130.3 & 130.5 & 130.7 & 130.9 & 131.2 & 131.4 & 131.6 & 131.8 & 129.6 & 130.3 & 130.9 & 131.6 & 130.6 \\
\hline 1991 & 132.0 & 132.2 & 132.5 & 132.7 & 132.9 & 133.1 & 133.3 & 133.5 & 133.7 & 133.9 & 134.2 & 134.4 & 132.2 & 132.9 & 133.5 & 134.2 & 133.2 \\
\hline 1992 & 134.6 & 134.9 & 135.2 & 135.5 & 135.7 & 136.0 & 136.3 & 136.6 & 136.8 & 137.1 & 137.4 & 137.7 & 134.9 & 135.7 & 136.6 & 137.4 & 136.1 \\
\hline 1993 & 138.0 & 138.2 & 138.5 & 138.8 & 139.1 & 139.4 & 139.7 & 139.9 & 140.2 & 140.5 & 140.8 & 141.1 & 138.2 & 139.1 & 139.9 & 140.8 & 139.5 \\
\hline 1994 & 141.5 & 141.9 & 142.3 & 142.7 & 143.1 & 143.6 & 144.0 & 144.4 & 144.9 & 145.3 & 145.7 & 146.2 & 141.9 & 143.1 & 144.4 & 145.7 & 143.8 \\
\hline \multirow[t]{2}{*}{1995} & 146.6 & 147.2 & 147.7 & 148.2 & 148.7 & 149.2 & 149.8 & 150.3 & 150.9 & 151.4 & $\ldots$ & $\ldots$ & 147.2 & 148.7 & 150.3 & $\ldots$ & $\cdots$ \\
\hline & & & & & & & & & tilizatio & & & & & & & & \\
\hline 1988 & 83.2 & 83.1 & 83.2 & 83.6 & 83.4 & 83.3 & 83.6 & 83.8 & 83.7 & 83.7 & 84.3 & 84.6 & 83.2 & 83.5 & 83.7 & 84.2 & 83.6 \\
\hline 1989 & 85.2 & 84.2 & 84.6 & 84.6 & 84.0 & 83.7 & 82.5 & 82.7 & 82.2 & 81.7 & 81.8 & 81.8 & 84.6 & 84.1 & 82.5 & 81.7 & 83.2 \\
\hline 1990 & 81.6 & 82.2 & 82.4 & 81.5 & 81.8 & 81.7 & 81.3 & 81.6 & 81.4 & 80.8 & 79.7 & 79.2 & 82.0 & 81.7 & 81.4 & 79.9 & 81.3 \\
\hline 1991 & 78.3 & 77.5 & 76.6 & 76.8 & 77.2 & 78.0 & 78.2 & 78.3 & 78.9 & 78.9 & 78.6 & 78.2 & 77.5 & 77.3 & 78.5 & 78.6 & 78.0 \\
\hline 1992 & 78.1 & 78.5 & 79.1 & 79.4 & 79.7 & 79.5 & 80.0 & 79.8 & 79.7 & 80.0 & 80.3 & 80.1 & 78.6 & 79.6 & 79.8 & 80.2 & 79.5 \\
\hline 1993 & 80.6 & 80.6 & 80.5 & 80.7 & 80.2 & 80.0 & 80.4 & 80.2 & 80.7 & 80.6 & 81.0 & 81.7 & 80.6 & 80.3 & 80.4 & 81.1 & 80.6 \\
\hline 1994 & 81.7 & 82.2 & 82.8 & 83.0 & 83.2 & 83.2 & 83.3 & 83.6 & 83.5 & 83.9 & 84.2 & 84.7 & 82.2 & 83.2 & 83.4 & 84.3 & 83.3 \\
\hline 1995 & 84.6 & 84.2 & 84.0 & 83.3 & 82.8 & 82.6 & 82.3 & 82.8 & 82.9 & 82.3 & $\ldots$ & $\ldots$ & 84.3 & 82.9 & 82.7 & 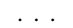 & $\ldots$ \\
\hline
\end{tabular}

For notes, see table 1.A. 
1. Revised and earlier industrial production, capacity, and utilization, 1985-95
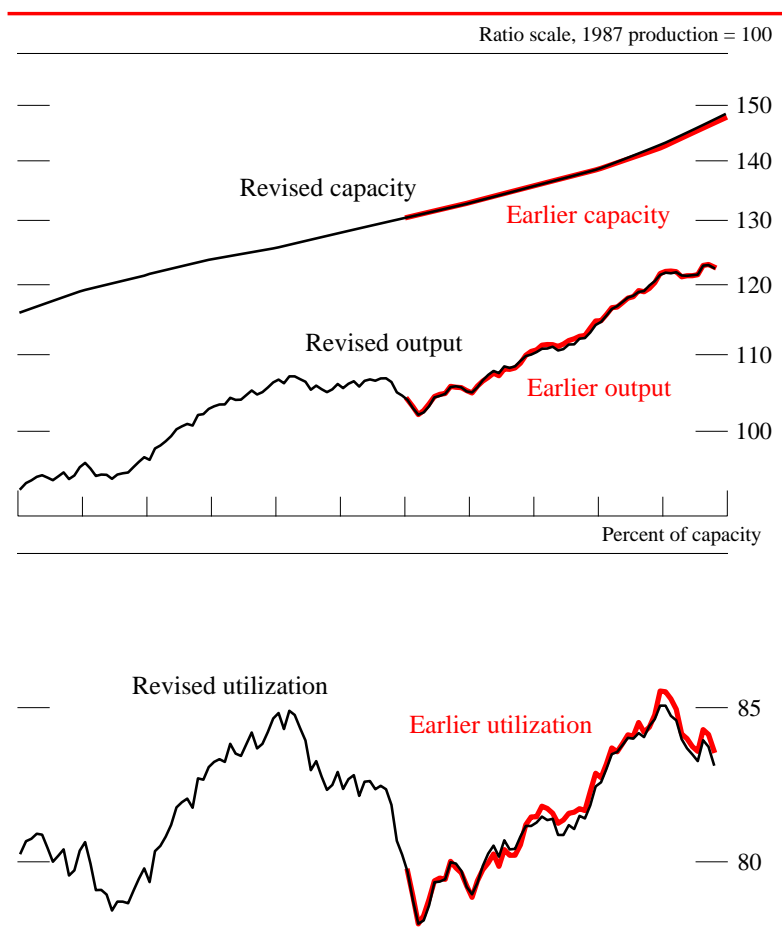

\begin{tabular}{lllll|l|l|l|} 
& $\mid$ & & & & $\mid$ & & \\
1985 & 1987 & 1989 & 1991 & 1993 & 1995 \\
\hline
\end{tabular}

Note. Seasonally adjusted, monthly data through October 1995. indexes for nondurable consumer goods and business supplies, which had grown at below average rates over the 1991-95 period, are now somewhat lower and show less growth in 1993 and 1995. The cumulative drop in the output of defense and space equipment is about the same-about a third from early 1991 through October 1995.

Among the major industry groups, the bulk of the revisions to the index for 1993 and 1994 were concentrated in manufacturing (table 3). Most notably, the growth in output of computer and office equipment was revised down sharply in 1993 and raised significantly in 1994 and 1995. In other manufacturing industries, the revision also produced some changes: The growth in electrical machinery and in chemicals in 1993 is now noticeably lower than previously estimated; however, the growth rates for these industries were revised up in 1994. The small downward revision to growth of total IP in 1995 reflected sizable revisions to both mining and utilities as well as a slight reduction in the growth in manufacturing.

\section{CAPACITY AND UTILIZATION}

The new estimates of capacity and utilization also incorporate new data as well as the revised production indexes. The new data include preliminary survey data on manufacturing utilization rates, typically

2. Revised rates of growth in industrial production, by major market group, 1991-95

\begin{tabular}{|c|c|c|c|c|c|c|c|c|c|c|}
\hline \multirow[t]{2}{*}{ Market group } & \multicolumn{5}{|c|}{$\begin{array}{l}\text { Revised rate of growth }{ }^{1} \\
\text { (percent) }\end{array}$} & \multicolumn{5}{|c|}{$\begin{array}{l}\text { Difference between revised } \\
\text { and earlier growth rates } \\
\text { (percentage points) }\end{array}$} \\
\hline & 1991 & 1992 & 1993 & 1994 & 1995 & 1991 & 1992 & 1993 & 1994 & 1995 \\
\hline Total index & .2 & 4.0 & 3.2 & 6.6 & 2.0 & .0 & .0 & -.4 & 6 & -.2 \\
\hline Products, total ... & -.3 & 4.1 & 2.5 & 5.6 & 1.6 & -.2 & -.2 & -.4 & 6 & -.5 \\
\hline Final products ..... & .3 & 4.4 & 2.5 & 5.4 & 2.4 & -.3 & -.2 & -.3 & .8 & -.5 \\
\hline Consumer goods & 2.7 & 3.4 & 1.9 & 4.1 & 1.0 & .2 & .0 & -.2 & .7 & -.4 \\
\hline Durable ........ & 5.9 & 6.9 & 10.6 & 6.1 & -2.5 & .5 & .4 & 2.4 & 1.0 & .6 \\
\hline Automotive products & 6.7 & 11.4 & 14.4 & 7.3 & -2.4 & 1.4 & -.5 & 2.9 & .0 & 1.3 \\
\hline Other durable goods . & 5.3 & 3.2 & 7.3 & 4.9 & -2.5 & -.1 & .9 & 1.9 & 1.8 & .0 \\
\hline Nondurable $\ldots . . . \ldots \ldots$ & 1.8 & 2.6 & -.2 & 3.5 & 2.0 & .0 & .0 & -.9 & .6 & -.6 \\
\hline Equipment, total ......... & -2.8 & 5.8 & 3.5 & 7.5 & 4.4 & -.8 & -.5 & -.4 & 1.1 & -.6 \\
\hline Business equipment $\ldots \ldots \ldots \ldots \ldots \ldots$ & .1 & 8.2 & 5.9 & 11.4 & 6.3 & -.7 & -.8 & -1.0 & 1.8 & -.4 \\
\hline Industrial $\ldots \ldots \ldots \ldots \ldots \ldots \ldots$ & -6.9 & 4.4 & 5.9 & 8.6 & 4.0 & -.2 & .9 & -.1 & -.1 & -.7 \\
\hline Information processing and related & 3.7 & 14.9 & 7.5 & 17.8 & 13.2 & -.8 & -1.6 & -3.1 & 4.1 & .6 \\
\hline 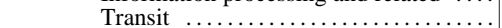 & 5.8 & .5 & .9 & 2.6 & -2.3 & -2.1 & -.6 & 3.6 & 2.4 & -3.0 \\
\hline 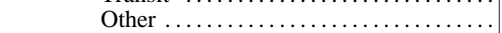 & -5.4 & 4.8 & 10.0 & 7.9 & -3.2 & -.1 & -1.9 & -1.8 & -2.5 & -1.2 \\
\hline Defense and space equipment $\ldots \ldots$. & -9.3 & -5.8 & -7.0 & -10.4 & -6.6 & -1.2 & .2 & 2.8 & -1.0 & -1.1 \\
\hline Intermediate products $\ldots \ldots \ldots \ldots \ldots \ldots \ldots$ & -2.2 & 3.2 & 2.6 & 6.3 & -.8 & .3 & -.1 & -.8 & .0 & -.5 \\
\hline Construction supplies $\ldots \ldots \ldots \ldots \ldots \ldots \ldots$ & -3.6 & 4.0 & 6.0 & 8.0 & -2.5 & .0 & -.3 & -.2 & -.4 & -.2 \\
\hline Business supplies $\ldots \ldots \ldots \ldots \ldots \ldots \ldots \ldots$ & -1.4 & 2.7 & 6 & 5.3 & .3 & .5 & -.1 & -1.3 & .2 & -.6 \\
\hline Materials $\ldots \ldots \ldots \ldots \ldots \ldots \ldots \ldots \ldots \ldots \ldots$ & .9 & 3.7 & 4.2 & 8.1 & 2.6 & .2 & .0 & -.4 & .6 & .2 \\
\hline Durable $\ldots \ldots \ldots \ldots \ldots \ldots \ldots \ldots$ & 1.5 & 6.2 & 7.2 & 11.2 & 4.6 & .6 & .0 & -.2 & .5 & .2 \\
\hline Nondurable..$\ldots \ldots \ldots \ldots \ldots \ldots \ldots \ldots$ & .4 & 2.3 & 2.3 & 6.9 & -2.2 & -.3 & .2 & -1.7 & 1.3 & 1.1 \\
\hline Energy $\ldots \ldots \ldots \ldots \ldots \ldots \ldots \ldots \ldots \ldots \ldots \ldots \ldots \ldots$ & .1 & .0 & -.5 & 1.9 & 2.3 & -.1 & .1 & .4 & .1 & -1.0 \\
\hline \multicolumn{11}{|l|}{$\begin{array}{l}\text { Aggregates, excluding computer } \\
\text { and office equipment }\end{array}$} \\
\hline Total index $\ldots \ldots \ldots \ldots \ldots \ldots$ & .0 & 3.3 & 2.8 & 6.1 & 1.2 & .0 & -.1 & -.3 & .5 & -.4 \\
\hline Business equipment $\ldots \ldots \ldots \ldots \ldots \ldots \ldots \ldots \ldots \ldots$ & -1.2 & 4.8 & 3.5 & 8.6 & 1.7 & -.8 & -.5 & -.3 & .7 & -1.3 \\
\hline
\end{tabular}


at the two-digit level in the Standard Industrial Classification (SIC), for the fourth quarters of 1993 and 1994 from the Bureau of the Census and updated information on physical capacity and utilization in selected industries for 1994 and 1995 as reported mainly by trade associations. In estimating capacity for most manufacturing industries, the annual growth is related to the growth in the industry's capital input. The estimates of capital input were revised as a result of the inclusion of investment data from the 1993 Annual Survey of Manufactures and updated results from the 1995 Investment Plans Survey by the Bureau of the Census.

Industrial capacity is now estimated to have expanded a bit faster over 1991-95. As before, sharp increases in actual and planned investment spending led to an estimated acceleration of capacity growth in 1994 and 1995. The annual rate of growth of industrial capacity increased from 2.1 percent in 1992 and 1993 to 3.6 percent over the first three quarters of 1995. The upward revision occurred in 1994 and was concentrated in durable goods manufacturing, notably for steel, motor vehicles and parts, and office and computing equipment (table 4). Survey results suggest that operating rates in the computer industry were much lower than those previously estimated, and given the revised estimates for production, the lower operating rates imply that capacity growth was much higher. Among nondurable goods, capacity growth is now higher for textiles, apparel, and paper products, but lower for chemicals and products.

As a result of the revisions to the production and capacity indexes, capacity utilization-the ratio of output to capacity - is a fraction of a percentage point lower than the earlier estimate for the 1993-95 period (table 5). For the third quarter of 1995, capacity utilization in manufacturing is estimated at 82.7 percent, 0.3 percentage point below the rate previously estimated. Besides the large downward revision in the operating rate for the computer industry, the revisions lowered the estimates of utilization rates for the plastics materials and the electrical machinery industries. Within manufacturing, the downward revision to utilization is sizable, both for durable manufacturing and for advanced-processing industries. Among primary-processing industries, operating rates were altered little, on balance, in 1994 and 1995; upward revisions to primary metals and to petroleum products offset downward revisions in other categories.

The capacity growth estimate for mining revised up a bit, and utilization was 0.8 percentage point lower in the third quarter of 1995. The utilization rate for utilities was raised largely because the

\section{Industrial production by market groups, 1989-95}

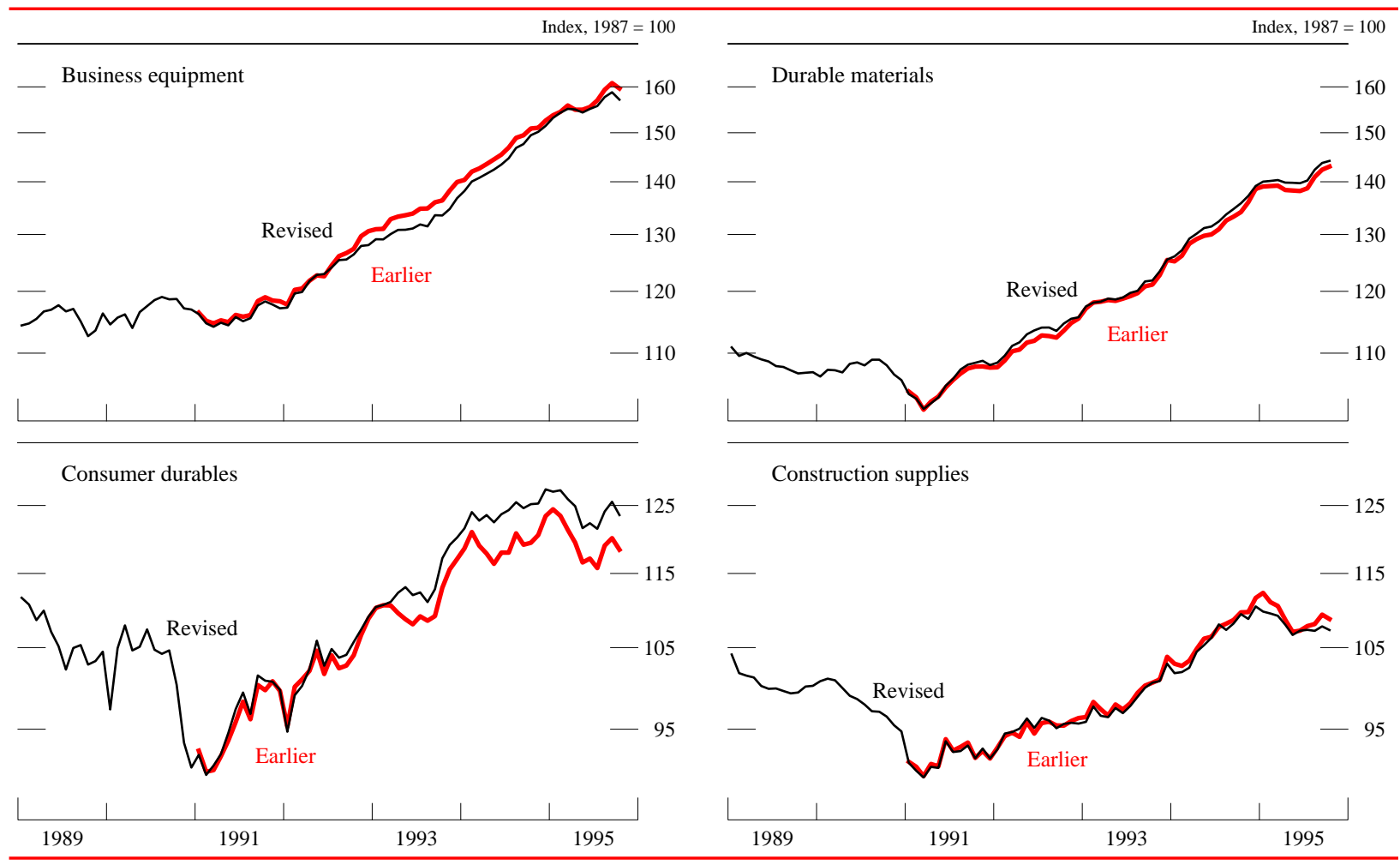

Note. Seasonally adjusted, monthly data through October 1995. 
North American Electric Reliability Council reported slower growth in generating capacity. The strong demand for electricity to operate air conditioners during last summer's heat wave increased the operating rate at electric utilities to a relatively high level.

\section{METHODOLOGICAL ASPECTS OF THE REVISION}

The revision to the IP index and measures of capacity involved some small modifications to value-added weights, changes in series structure, and updating of monthly data on inputs to production. The most significant methodological change was the use of a different method of aggregation to estimate measures of industry capital input, which are used in estimating capacity.

\section{Weighting of the Indexes}

To combine individual series into market or industry aggregates, the individual indexes are multiplied by their proportionate contribution to industrial value added in 1992. As in the revision a year ago, the 1992 Census of Manufactures and the 1992 Census of Mineral Industries were used for measures of value

3. Revised rates of growth in industrial production, by major industry group, 1991-95

\begin{tabular}{|c|c|c|c|c|c|c|c|c|c|c|c|}
\hline \multirow[t]{2}{*}{ Industry group } & \multirow{2}{*}{$\begin{array}{l}\text { SIC } \\
\operatorname{code}^{1}\end{array}$} & \multicolumn{5}{|c|}{$\begin{array}{l}\text { Revised rate of growth }{ }^{2} \\
\text { (percent) }\end{array}$} & \multicolumn{5}{|c|}{$\begin{array}{l}\text { Difference between revised } \\
\text { and earlier growth rates } \\
\text { (percentage points) }\end{array}$} \\
\hline & & 1991 & 1992 & 1993 & 1994 & 1995 & 1991 & 1992 & 1993 & 1994 & 1995 \\
\hline Total index . & & .2 & 4.0 & 3.2 & 6.6 & 2.0 & .0 & .0 & -.4 & 6 & -.2 \\
\hline Manufacturing. & & .3 & 4.5 & 3.7 & 7.6 & 1.6 & .1 & -.1 & -.5 & .7 & -.1 \\
\hline Primary processing ... & & -.6 & 4.0 & 4.3 & 7.0 & -1.7 & .0 & .2 & -.8 & 6 & .5 \\
\hline Advanced processing & & .6 & 4.7 & 3.4 & 7.8 & 3.0 & .0 & -.3 & -.3 & .7 & -.3 \\
\hline Durable $\ldots \ldots \ldots \ldots \ldots$ & & .0 & 5.5 & 6.2 & 9.3 & 3.3 & .0 & -.3 & -.1 & .8 & .0 \\
\hline Lumber and products & 24 & -.5 & 5.8 & 3.9 & 5.7 & -2.0 & -.3 & -1.5 & -1.8 & 1.6 & 1.0 \\
\hline Furniture and fixtures $\ldots \ldots \ldots$ & 25 & -.5 & 4.9 & 5.2 & 7.3 & -3.0 & .5 & -.6 & .7 & -.7 & -2.3 \\
\hline Stone, clay, and glass products .. & 32 & -5.7 & 3.8 & 4.2 & 4.0 & -1.8 & 1.1 & -1.9 & -.8 & -1.5 & .5 \\
\hline Primary metals & 33 & -3.1 & 1.0 & 7.5 & 9.8 & -4.3 & -.2 & -.1 & .7 & 1.0 & .5 \\
\hline Iron and steel & 331,2 & -5.4 & 1.1 & 9.1 & 8.3 & -3.0 & -.2 & -.5 & .9 & .7 & 1.7 \\
\hline Raw steel & & -8.5 & 1.6 & 5.8 & 6.4 & 4 & -.3 & -.1 & -.1 & .0 & 1.2 \\
\hline Nonferrous.$\ldots \ldots \ldots$ & $333-6,9$ & .4 & .9 & 5.4 & 11.8 & -6.0 & -.2 & .6 & .3 & 1.4 & -1.1 \\
\hline Fabricated metal products $\ldots \ldots \ldots \ldots$ & 34 & -1.8 & 5.1 & 3.9 & 8.4 & .8 & -.4 & .6 & -1.0 & .8 & -.5 \\
\hline Industrial machinery and equipment & 35 & -1.6 & 10.4 & 12.9 & 14.9 & 10.7 & -.4 & -.9 & -1.2 & 1.7 & 1.8 \\
\hline Computer and office equipment .. & 357 & 5.5 & 28.0 & 26.7 & 29.6 & 32.7 & -.1 & -2.6 & -6.8 & 9.4 & 4.6 \\
\hline Electrical machinery $\ldots \ldots \ldots \ldots .$. & 36 & 5.3 & 9.9 & 8.2 & 17.7 & 12.5 & 1.3 & -1.5 & -4.9 & 1.2 & -.5 \\
\hline Transportation equipment ... & 37 & .8 & 2.9 & 4.9 & 3.2 & -3.3 & -.4 & .6 & 4.4 & .7 & -.5 \\
\hline Motor vehicles and parts & 371 & 10.0 & 10.7 & 16.8 & 8.6 & -3.4 & -.2 & -1.0 & 2.8 & .7 & 1.5 \\
\hline Autos and light trucks $\ldots$ & & 12.3 & 8.8 & 15.7 & 6.0 & -3.9 & -.4 & .0 & .8 & -.1 & 2.1 \\
\hline Aerospace and miscellaneous & $372-6,9$ & -6.3 & -4.3 & -7.9 & -4.1 & -3.2 & -.5 & 2.0 & 6.5 & 1.5 & -3.8 \\
\hline Instruments $\ldots \ldots \ldots \ldots \ldots \ldots$ & 38 & .0 & 1.0 & -1.1 & 4.0 & .9 & -.7 & .5 & 1.0 & .8 & .2 \\
\hline Miscellaneous $\ldots \ldots \ldots \ldots \ldots \ldots \ldots$ & 39 & .3 & 2.1 & 6.0 & 6.2 & .0 & -.2 & 1.5 & 2.2 & .1 & 1.4 \\
\hline Nondurable & & .6 & 3.2 & .9 & 5.5 & -.6 & .1 & .0 & -.9 & .5 & -.2 \\
\hline Foods $\ldots \ldots \ldots$ & 20 & .9 & 1.6 & 2.6 & 3.6 & 1.2 & .1 & -.3 & .5 & .1 & -1.1 \\
\hline Tobacco products $\ldots \ldots \ldots \ldots \ldots$ & 21 & -11.8 & 5.6 & -19.6 & 24.7 & 4.3 & .3 & -4.4 & -4.1 & -2.2 & 4.5 \\
\hline Textile mill products $\ldots \ldots \ldots \ldots \ldots \ldots \ldots$ & 22 & 5.0 & 6.3 & 4.6 & 5.0 & -6.3 & -.6 & 1.9 & 3.2 & -.5 & 2.2 \\
\hline Apparel products .................... & 23 & 5.8 & .9 & 1.3 & 4.0 & -9.1 & -.1 & .9 & 2.5 & 1.3 & .6 \\
\hline Paper and products.$\ldots \ldots \ldots \ldots \ldots \ldots \ldots$ & 26 & 2.0 & .4 & 6.8 & 4.2 & -2.6 & .2 & .8 & -.4 & .3 & -.7 \\
\hline Printing and publishing . & 27 & -1.9 & 2.3 & -1.4 & 2.6 & -1.1 & .5 & .2 & -1.2 & .0 & .4 \\
\hline Chemicals and products $\ldots \ldots \ldots$ & 28 & .2 & 4.4 & -1.0 & 7.0 & 1.4 & -.3 & .0 & -4.0 & 2.3 & -1.0 \\
\hline Petroleum products $\ldots . . \ldots$. & 29 & -1.6 & 3.6 & 3.1 & .0 & 2.7 & .4 & .3 & .6 & -.4 & 1.6 \\
\hline Rubber and plastics products ... & 30 & 3.4 & 8.7 & 6.7 & 10.4 & -1.6 & .2 & .3 & .7 & .3 & .1 \\
\hline Leather and products $\ldots \ldots \ldots \ldots \ldots \ldots$ & 31 & -4.5 & 5.1 & -2.6 & -3.2 & -9.4 & 1.2 & -.2 & 2.2 & -1.7 & 1.5 \\
\hline Mining ......... & & -3.1 & .3 & -.5 & 1.2 & .4 & .0 & .0 & .3 & .4 & -1.4 \\
\hline Metal mining $\ldots \ldots \ldots \ldots \ldots \ldots \ldots \ldots \ldots$ & 10 & -.4 & 6.1 & 2.5 & -2.8 & 7.5 & -.6 & .3 & 1.8 & 2.3 & -.9 \\
\hline Coal mining $\ldots \ldots \ldots \ldots \ldots \ldots \ldots \ldots \ldots$ & 12 & -2.0 & -.5 & -3.2 & 9.1 & .5 & .5 & .2 & .1 & -.1 & 1.1 \\
\hline Oil and gas extraction $\ldots \ldots \ldots \ldots$ & 13 & -3.5 & -.5 & -.6 & -.7 & -1.0 & -.2 & .1 & .3 & .4 & -2.1 \\
\hline Stone and earth minerals ... & 14 & -4.5 & 4.5 & 2.9 & 6.4 & 4.8 & .6 & -.3 & .2 & -.4 & -1.5 \\
\hline Utilities ... & & 2.7 & 2.0 & 1.5 & .2 & 9.1 & .1 & .1 & .4 & .0 & -1.1 \\
\hline Electric ... & $491,3 \mathrm{pt}$ & 1.6 & 1.9 & .9 & 1.8 & 8.4 & .1 & .0 & .3 & -.1 & -1.1 \\
\hline Gas $\ldots . . .$. & $492,3 \mathrm{pt}$ & 7.0 & 2.1 & 3.9 & -6.0 & 11.9 & .2 & .2 & .7 & .0 & -.9 \\
\hline $\begin{array}{l}\text { Aggregates, excluding computer } \\
\text { and office equipment }\end{array}$ & & & & & & & & & & & \\
\hline Manufacturing $\ldots \ldots \ldots \ldots \ldots \ldots$ & & .0 & 3.7 & 3.2 & 7.0 & 6 & .0 & -.1 & -.3 & .5 & -.2 \\
\hline
\end{tabular}

1. Standard Industrial Classification.

2. Growth rates are calculated as the percentage change in the seasonally adjusted index from the fourth quarter of the previous year to the fourth quarter

of the year specified in the column heading. For 1995, the annual growth rates are calculated from the fourth quarter of 1994 to the third quarter of 1995. 
added by individual manufacturing and mining industries. Value-added estimates for electric and gas utilities were compiled from income and expense information published by the Department of Energy, the Edison Electric Institute, and the American Gas Association.

Although the overall 1992 value-added weights were essentially unchanged in this revision, the weights of some series were modified to reflect small changes to value-added data as initially reported in the 1992 preliminary Census of Manufactures and preliminary Census of Mineral Industries. In addition, weights for detailed series (typically product series or series split according to market group) below the four-digit SIC level were adjusted to reflect some data on the 1992 value of product that were not available for the 1994 revision.

This revision updates the supplementary series on the gross value of products. The gross value series are derived from production indexes for products, and they exclude materials series to avoid double counting. Formerly in 1987 dollars, the gross value

4. Revised rates of growth in capacity, by major industry group, 1991-95

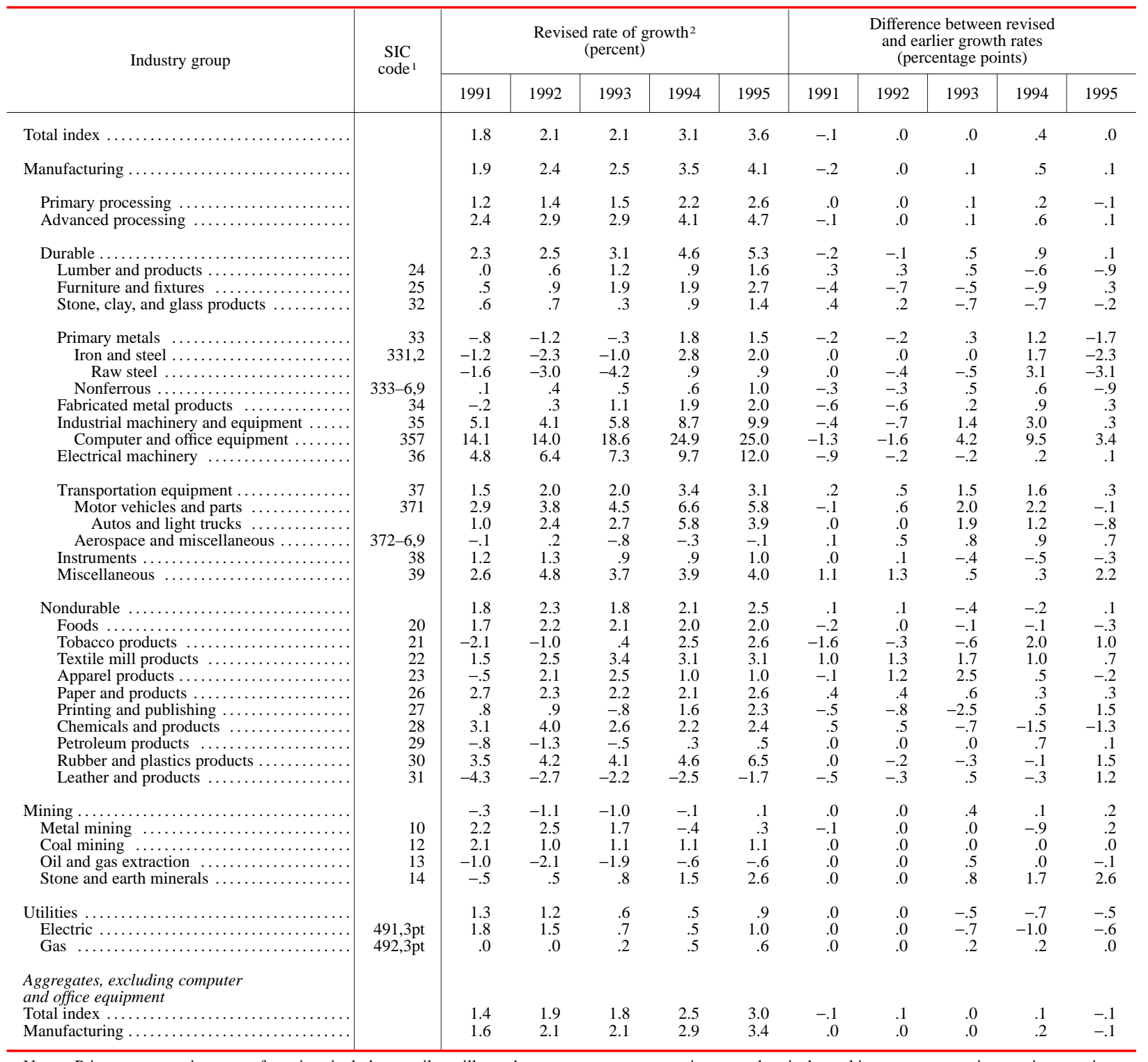

Note. Primary processing manufacturing includes textile mill products, paper and products, industrial chemicals, synthetic materials, and fertilizers, petroleum products, rubber and plastics products, lumber and products, primary metals, fabricated metals, and stone, clay, and glass products. Advanced processing manufacturing includes foods, tobacco products, apparel products, printing and publishing, chemical products and other agricultural chemicals, leather and products, furniture and fixtures, industrial and commercial machinery and

computer equipment, electrical machinery, transportation equipment, instruments, and miscellaneous manufactures.

1. Standard Industrial Classification.

2. Growth rates are calculated as the percentage change in the seasonally adjusted index from the fourth quarter of the previous year to the fourth quarter of the year specified in the column heading. For 1995, the annual growth rates are calculated from the fourth quarter of 1994 to the third quarter of 1995. 
series are now expressed in 1992 dollars. The dollar weights that are applied to individual manufacturing series are derived from the value of products figures from the 1992 Census of Manufactures.

\section{Changes in Series Structure}

The series structure of the index of industrial production, which now comprises 260 individual series, remains basically the same. To improve coverage and reliability, a net of five series were added and source data for three other series were modified. With the changes, the proportion of the IP series derived from physical product data rises 2 percentage points, in 1992 value-added terms, to 41 percent.

Industrial organic chemicals (SIC 286), formerly an input-based series, is now derived from quarterly production data reported by the National Petroleum Refiners Association. These data cover major petrochemicals, such as benzene, ethylene, propylene, and styrene. The production quantity of each chemical is multiplied by an estimate of value added per unit in 1992.

5. Revised capacity utilization rates, by major industry group

\begin{tabular}{|c|c|c|c|c|c|c|c|c|c|c|c|}
\hline \multirow{2}{*}{ Industry group } & \multirow{2}{*}{$\begin{array}{l}\text { SIC } \\
\operatorname{code}^{1}\end{array}$} & \multicolumn{6}{|c|}{$\begin{array}{c}\text { Revised rate } \\
\text { (percentage of capacity) }\end{array}$} & \multicolumn{4}{|c|}{$\begin{array}{l}\text { Difference between revised } \\
\text { and earlier growth rates } \\
\text { (percentage points) }\end{array}$} \\
\hline & & $\begin{array}{l}\text { 1967-94 } \\
\text { avg. }\end{array}$ & $\begin{array}{c}\text { 1989-90 } \\
\text { high }\end{array}$ & $\begin{array}{c}1991-92 \\
\text { low }\end{array}$ & 1993:Q4 & 1994:Q4 & 1995:Q3 & $\begin{array}{c}1991-92 \\
\text { low }\end{array}$ & 1993:Q4 & 1994:Q4 & 1995:Q3 \\
\hline Total index ..... & & 81.8 & 84.9 & 78.0 & 81.9 & 84.7 & 83.6 & .0 & -.4 & -.2 & -.4 \\
\hline Manufacturing . & & 81.1 & 85.2 & 76.6 & 81.1 & 84.3 & 82.7 & .0 & -.4 & -.2 & -.3 \\
\hline Primary processing ... & & 82.4 & 89.0 & 77.9 & 85.2 & 89.3 & 86.4 & .0 & -.6 & -.2 & .2 \\
\hline Advanced processing & & 80.5 & 83.5 & 76.1 & 79.3 & 82.1 & 81.1 & .0 & -.4 & -.4 & -.6 \\
\hline Durable $\ldots \ldots \ldots \ldots \ldots$ & & 78.9 & 84.0 & 73.7 & 80.2 & 83.8 & 82.6 & -.1 & -.5 & -.7 & -.7 \\
\hline Lumber and products & 24 & 83.0 & 91.1 & 76.1 & 86.4 & 90.6 & 88.0 & -.3 & -4.0 & -2.1 & -.7 \\
\hline Furniture and fixtures $\ldots \ldots \ldots \ldots \ldots$ & 25 & 81.5 & 84.7 & 72.2 & 81.7 & 86.0 & 82.9 & 1.2 & 1.8 & 2.1 & 1.1 \\
\hline Stone, clay, and glass products ......... & 32 & 78.0 & 83.8 & 71.0 & 78.4 & 80.8 & 78.8 & -.5 & -1.0 & -1.8 & -1.3 \\
\hline Primary metals . & 33 & 80.3 & 92.8 & 74.2 & 88.4 & 95.3 & 91.3 & .2 & .4 & .1 & 1.6 \\
\hline Iron and steel . & 331,2 & 80.0 & 95.7 & 72.0 & 90.1 & 94.9 & 90.9 & -.1 & .1 & -.9 & 1.1 \\
\hline Raw steel .. & & 79.6 & 89.9 & 71.5 & 90.6 & 95.5 & 95.4 & .1 & .3 & -2.7 & .3 \\
\hline Nonferrous ..... & $333-6,9$ & 81.1 & 88.5 & 75.2 & 86.2 & 95.8 & 90.7 & .2 & 6 & 1.2 & 1.1 \\
\hline Fabricated metal products & 34 & 77.2 & 82.0 & 71.3 & 79.7 & 84.8 & 84.5 & -.4 & .1 & -.1 & -.1 \\
\hline Industrial machinery and equipment . & 35 & 80.6 & 84.0 & 71.8 & 82.5 & 87.2 & 87.6 & -.7 & -2.4 & -3.7 & -2.9 \\
\hline Computer and office equipment ... & 357 & 80.2 & 80.0 & 64.5 & 79.5 & 82.5 & 85.6 & -.1 & -7.1 & -7.7 & -8.3 \\
\hline Electrical machinery $\ldots \ldots \ldots \ldots \ldots \ldots$ & 36 & 80.3 & 84.2 & 77.0 & 81.6 & 87.7 & 87.6 & 1.5 & -2.8 & -2.2 & -2.6 \\
\hline Transportation equipment ... & 37 & 74.8 & 84.4 & 69.7 & 77.4 & 77.3 & 73.8 & -.5 & 1.8 & 1.2 & .7 \\
\hline Motor vehicles and parts & 371 & 76.0 & 85.1 & 56.6 & 83.6 & 85.1 & 79.7 & -1.0 & -.8 & -2.1 & -1.0 \\
\hline Autos and light trucks ${ }^{2} \ldots$ & & & 89.1 & 55.6 & 85.0 & 85.2 & 80.8 & -2.1 & -1.4 & -2.4 & -.4 \\
\hline Aerospace and miscellaneous & $372-6,9$ & 74.9 & 88.4 & 75.6 & 70.4 & 67.8 & 66.2 & 1.2 & 4.9 & 5.2 & 3.0 \\
\hline Instruments $\ldots \ldots \ldots \ldots \ldots \ldots$ & 38 & 81.8 & 80.8 & 76.4 & 75.6 & 78.0 & 78.5 & -.3 & .9 & 1.9 & 2.8 \\
\hline Miscellaneous $\ldots \ldots \ldots \ldots \ldots . . .$. & 39 & 75.1 & 79.8 & 72.1 & 74.1 & 75.8 & 73.4 & -.8 & .3 & .2 & -.4 \\
\hline Nondurable $\ldots \ldots \ldots \ldots \ldots \ldots$ & & 83.4 & 86.7 & 80.3 & 82.0 & 84.7 & 82.8 & -.1 & -.4 & .1 & .0 \\
\hline Foods $\ldots \ldots \ldots \ldots \ldots \ldots \ldots \ldots$ & 20 & 82.2 & 83.3 & 80.8 & 81.6 & 82.9 & 82.3 & .3 & .6 & .7 & .0 \\
\hline Tobacco products $\ldots$ & 21 & 90.8 & 102.4 & 76.7 & 71.1 & 86.5 & 86.3 & -.4 & -4.5 & -9.0 & -7.9 \\
\hline Textile mill products & 22 & 86.1 & 92.1 & 78.8 & 88.9 & 90.5 & 84.3 & -.1 & .4 & -.9 & .3 \\
\hline Apparel products ............ & 23 & 80.9 & 82.3 & 75.0 & 78.9 & 81.3 & 74.8 & -.1 & -.2 & .3 & .6 \\
\hline Paper and products $\ldots \ldots \ldots \ldots \ldots \ldots \ldots$ & 26 & 89.8 & 94.6 & 86.7 & 91.9 & 93.8 & 90.1 & .2 & -.6 & -.6 & -1.3 \\
\hline Printing and publishing . & 27 & 86.0 & 90.4 & 78.9 & 81.2 & 82.0 & 79.9 & .7 & 2.5 & 2.2 & 1.5 \\
\hline Chemicals and products $\ldots$ & 28 & 79.9 & 85.5 & 78.5 & 77.1 & 80.7 & 80.1 & -.4 & -3.6 & -.7 & -.6 \\
\hline Petroleum products $\ldots \ldots \ldots$. & 29 & 85.4 & 91.4 & 84.6 & 93.0 & 92.7 & 94.1 & .9 & 1.2 & .2 & 1.2 \\
\hline Rubber and plastics products .. & 30 & 84.1 & 90.5 & 78.0 & 88.8 & 93.7 & 88.0 & -.4 & 1.4 & 1.8 & .8 \\
\hline Leather and products $\ldots \ldots \ldots \ldots \ldots \ldots$ & 31 & 82.0 & 84.9 & 76.0 & 85.4 & 84.8 & 79.5 & 1.3 & 3.1 & 1.9 & 1.8 \\
\hline Mining $\ldots \ldots \ldots$ & & 87.6 & 89.5 & 85.6 & 88.1 & 89.3 & 89.5 & -.1 & .0 & .3 & -.8 \\
\hline Metal mining & 10 & 78.5 & 88.8 & 80.0 & 86.4 & 84.4 & 88.6 & -.6 & 1.3 & 4.0 & 3.6 \\
\hline Coal mining $\ldots \ldots \ldots$ & 12 & 86.7 & 93.5 & 82.6 & 80.2 & 86.6 & 86.2 & .3 & .7 & .7 & 1.4 \\
\hline Oil and gas extraction $\ldots \ldots \ldots$ & 13 & 88.4 & 90.7 & 86.0 & 90.3 & 90.2 & 90.0 & .1 & -.2 & .3 & -1.1 \\
\hline Stone and earth minerals $\ldots \ldots \ldots \ldots \ldots$ & 14 & 84.3 & 90.0 & 79.4 & 86.2 & 90.3 & 91.6 & .0 & -.5 & -2.4 & -5.3 \\
\hline Utilities ........... & & 86.5 & 92.6 & 83.1 & 87.3 & 87.1 & 92.2 & -.1 & .9 & 1.4 & 1.2 \\
\hline Electric $\ldots \ldots \ldots \ldots \ldots \ldots \ldots \ldots$ & $491,3 \mathrm{pt}$ & 88.5 & 94.8 & 84.4 & 88.3 & 89.5 & 94.3 & -.4 & 9 & 1.7 & 1.5 \\
\hline 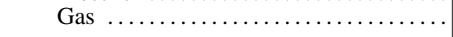 & $492,3 \mathrm{pt}$ & 82.3 & 85.5 & 71.2 & 83.6 & 78.2 & 84.7 & -.2 & .7 & .6 & .1 \\
\hline \multicolumn{12}{|l|}{$\begin{array}{l}\text { Aggregates, excluding computer } \\
\text { and office equipment }\end{array}$} \\
\hline Total index $\ldots \ldots \ldots \ldots \ldots \ldots \ldots \ldots$ & & 81.5 & 85.0 & 78.3 & 81.9 & 84.7 & 83.5 & .0 & -.2 & .0 & -.2 \\
\hline Manufacturing $\ldots \ldots \ldots \ldots \ldots \ldots \ldots \ldots \ldots$ & & 80.7 & 85.3 & 76.9 & 81.0 & 84.2 & 82.4 & .0 & -.4 & -.2 & -.3 \\
\hline
\end{tabular}

NoTE. The "high" columns refer to periods in which utilization generally peaked; the "low" columns refer to recession years in which utilization gener-

1. Standard Industrial Classification ally bottomed out. The monthly highs and lows are specific to each series, and 
Before the current revision, three unpublished series represented service industry machines (SIC 358). As part of the revision, six individual IP series, four of which are new, were used to construct a new aggregate index for the industry's largest fourdigit component, heating and refrigeration equipment (SIC 3585). The following new series were added to the existing series on room air conditioners and unitary air conditioners: (1) an estimate of air conditioners for motor vehicles that uses motor vehicle assemblies as a monthly indicator and that is based on the annual output in units reported by the Census Bureau; (2) an index for warm air furnaces based on data in units reported by the Gas Appliance Manufacturers Association; (3) an estimate of commercial heating and cooling equipment developed from annual output in units reported by the Census Bureau; and (4) an estimate of compressors, condensers, and other parts for heating and cooling equipment (including home appliances) based on unit output of the assembled equipment.

The plumbing and heating products group (SIC 343), which had been covered by one inputbased series, has been split into three series. The first is plumbing fixtures (SIC 3431,2), which is based on monthly kilowatt hours. The other two series cover SIC 3433: (1) boilers, unit heaters, and furnaces, except warm air, a series based on units reported by the Gas Appliance Manufacturers Association, and (2) burners and parts for boilers, water heaters, and furnaces, a series based on source data for related IP indexes.

The monthly series on household audio and video equipment (SIC 3651) is now based solely on units of direct-view color television sets, with screens that measure at least 19 inches, as reported by the Electronic Industries Association, less comparable imports. Monochromatic TVs and smaller color TVs are no longer produced in the United States.

Formerly, the output of carpets (SIC 227) was represented by two series based on shipments of woven and tufted carpets. Because the Carpet and Rug Institute has discontinued issuing data on woven carpets, this small series has been dropped. In the revised IP index, the carpet industry is now represented by only production of tufted carpets, which accounts for the bulk of carpet output.

\section{New Monthly Data and Seasonal Factors in the Production Indexes}

Series based on input measures are used to estimate monthly production indexes for more than half of industrial production. These measures, either monthly production worker hours or kilowatt-hours of electricity consumed by industry, were revised in three main ways. First, the monthly production worker hours data were revised by the Bureau of Labor Statistics to reflect the benchmarking of monthly employment data to the number of employees covered by unemployment insurance in March 1994. As a result of the benchmarking, employment in manufacturing rose and employment in mining declined slightly. Second, as part of a major revision of the electric power data collected by the Federal Reserve, revised kilowatt-hour data on the sales of electric power to industries since 1990 have been introduced in this revision. The new estimates more accurately account for cogeneration and are benchmarked to electric power use reported in the Census and Annual Survey of Manufactures. After the completion of review and documentation, the revised electric power series back to 1972 will be published in a supplement to the Federal Reserve's statistical release G.17 "Industrial Production and Capacity Utilization." Third, new productivity factors were applied to input data since 1991, based on productivity trends derived from annual input and output data.

Monthly physical output measures in tons, barrels, and so on were also updated. In many cases, the monthly product data are not comprehensive and may cover only part of the output of an industry. In such instances, the updated monthly product data are adjusted to annual levels based on more comprehensive annual indexes of output, such as those provided by the Bureau of the Census and the Bureau of Mines.

Seasonal factors based on the X-11 ARIMA model were calculated through mid-1995. When appropriate, the original observations are modified before applying the X-11 program so that abrupt changes due to business cycles or other causes do not distort the factors. Moreover, each of the main types of monthly data involves some custom handling. For example, physical product data are expressed as daily averages before seasonal adjustment to adjust for the different numbers of working days per week in different industries.

Seasonal adjustment of the series for production worker hours - the product of employment and the length of the workweek - requires some special treatment because the monthly BLS employment survey covers only the pay period that includes the twelfth of the month. Two special kinds of preadjustments are made before using X-11 ARIMA. The length of the workweek is affected by holidays that fall within the survey period because overtime hours are typically 
reduced. Thus an adjustment to the workweek is made when a holiday such as Easter or Labor Day falls in the survey week. Adjustments are also made to account for the interval between surveys, which may be either four or five weeks. The size of the interval adjustment tends to be larger at times when monthly movements in the unadjusted hours series are particularly large.

Seasonal factors for the electric power data were reestimated on the basis of data through March 1995. In estimating the seasonal factors for the revised kilowatt-hour series, the original observations were initially modified to remove abrupt changes that might distort the factors. The modified series were then seasonally adjusted by the X-11 ARIMA program. After the first adjustment, the seasonal factors for individual series within two-digit SIC groups were pooled to more efficiently estimate common seasonal patterns. The seasonal factors for individual series resulting from the joint seasonal estimation technique exhibit reduced sensitivity to random shocks and are less prone to revision when new data are added. ${ }^{1}$

\section{Revised Estimates of Industrial Capacity}

The revised capacity indexes, which are designed to accompany the production indexes, incorporate the new IP indexes as well as updated measures of capital input and the latest utilization rates from various sources. The latest Census survey of manufacturing plant utilization, a major source of new data, provided preliminary utilization rates through 1993 and 1994, mainly at the two-digit SIC level. For those industries that provide utilization rates as well as output and capacity data expressed in physical units, the data were updated for such items as raw steel, copper, plastics resins, automobiles and light truck assembly, and generation of electricity.

As a first step in estimating the capacity indexes, preliminary end-of-year indexes of industrial capacity $(I C)$ are calculated by dividing a production index $(I P)$ by a utilization rate obtained from a survey $\left(U_{s}\right)$ for that end-of-year period. Thus $I C_{t}=I P_{t} / U_{s, t}$. These preliminary indexes are indirect, or implied, estimates of capacity and are expressed, like the indexes of industrial production, as percentages of production in a base year, currently 1987. Each implied capacity

1. Eric J. Bartelsman and William P. Cleveland, "Joint Seasonal Adjustment of Economic Time Series," Finance and Economics Discussion Series No. 93-28 (August 1993), Board of Governors of the Federal Reserve System, Washington, D.C. index number is an estimate of sustainable potential output expressed as a percentage of output in 1987 and gives the general level and trend of capacity. ${ }^{2}$

The annual movements of the preliminary capacity indexes are then adjusted to give consideration to alternative indicators of annual capacity change; these alternatives include capacity data in physical units and estimates of capital input. In general, the adjusted estimates of capacity are the fitted values from regressions that recalibrate the physical capacity or capital input estimates to the trend growth path of the preliminary implied capacities:

$$
\left(I C_{t}=I P_{t} / U_{s, t}\right){ }^{3}
$$

In this revision, the capital measures used to calculate many series on manufacturing capacity have been reconfigured. As before, estimates are made of each industry's real net capital stock of a diverse set of assets. These real net capital stocks continue to be estimated by the perpetual inventory method. Elements included in these estimations are (1) time series of investments in new equipment and structures by three-digit manufacturing industries; (2) corresponding decompositions of the annual investments into twenty-nine asset types; (3) asset-type deflators and service lives; and (4) estimates of losses in capital efficiency because of discards and economic decay as assets age. ${ }^{4}$

2. For a discussion of the calculation of the utilization rates published by the Federal Reserve, see the appendix in Richard D. Raddock, "Recent Developments in Industrial Capacity and Utilization," Federal Reserve Bulletin, vol. 76 (June 1990), pp. 424-35.

3 . The fitted values from a regression of the equation below give an estimate of the difference in the trends of the implied capacity and the annual capacity indicator.

$$
\log \left(I C_{t} / K_{t}\right)=a+\sum_{1} b_{i} f_{i}(t)+e_{t},
$$

where

$$
\begin{aligned}
I C_{t} & =\text { implied capacity index in period } t \\
K_{t} & =\text { annual capacity indicator } \\
f_{i}(t) & =\text { specified functions of time } \\
a, b_{i} & =\text { parameters to be estimated } \\
e_{t} & =\text { error term. }
\end{aligned}
$$

The refined capacity estimates are taken to be the annual capacity indicators multiplied by the antilogarithms of the fitted values from the equation.

4. M.F. Mohr and C.E. Gilbert, "Capital Stock Estimates for Manufacturing Industries: Methods and Data" (Industrial Output Section, Division of Research and Statistics, Board of Governors of the Federal Reserve System, December 1995, unpublished). 


\section{Data Availability}

Current data are published monthly in the Federal Reserve's statistical release G.17 "Industrial Production and Capacity Utilization." The release as well as diskettes containing either historical data (through 1985) or more recent data (1986 through those most recently published in the G.17 statistical release) are available from Publications Services, Board of Governors of the Federal Reserve System, Washington, DC 20551 (202-452-3245). Files containing the revised data and the text and tables from the current release are also available through the Economic Bulletin Board of the Department of Commerce; for information call 202-482-1986.

A document with printed tables of the revised estimates of series shown in the G.17 release is also available on written request to the Industrial Output Section, Mail Stop 82, Division of Research and Statistics, Board of Governors of the Federal Reserve System, Washington, DC 20551.

Revisions to the growth in the constant-dollar net capital stocks for the different assets since 1990 are the result of incorporating new data from several sources. The data used were current-dollar expenditures on new capital, by industry, from the revised 1992 Census of Manufactures and the preliminary 1993 Annual Survey of Manufactures; revised estimates by the Bureau of Economic Analysis of both current-dollar new investment and related price defla- tors, by asset type, for 1994 through the second quarter of 1995; and revised estimates of 1995 investment by manufacturing industries in new plant and equipment from the latest Investment Plans Survey. Taken together, this new information led to lower estimates of the growth of the real capital stock over 1993-94 and about the same rate of growth in 1995 as previously indicated.

Formerly, the real net stocks of specific assets, such as computers, metalworking machinery, and industrial buildings, were simply summed to obtain an industry's total net capital stock. In this revision, a different method of aggregation was used to estimate industry capital input. The new capital input measures, which are calculated using a Tornqvist index number formula, weight growth rates in the net stocks of individual assets by an estimate of that asset's share of the aggregate marginal product of the industry's capital. 5 Following standard practice, assetspecific rental prices were constructed and used to approximate the profile of each asset's marginal product over time.

5. This method is similar to the one used by the Bureau of Labor Statistics to calculate multifactor productivity. The BLS capital input measures are documented in appendix C of Trends in Multifactor Productivity, 1948-81, Bulletin 2178 (U.S. Department of Labor, Bureau of Labor Statistics, 1983). For an early application of this method, see L.R. Christensen and D.W. Jorgenson, "The Measurement of U.S. Real Capital Input, 1929-67,' Review of Income and Wealth, Series 15 (December 1969), pp. 293-320. 